\title{
КОНЦЕПТУАЛЬНІ УЗАГАЛЬНЕННЯ ЩОДО СТРУКТУРНОЇ ОРГАНІЗАЦІЇ КОМП'ЮТЕРНИХ МЕРЕЖ ВИЩИХ МЕДИЧНИХ НАВЧАЛЬНИХ ЗАКЛАДІВ
}

\author{
О. П. Мінцер, О. А. Рижов ${ }^{1}$, В. П. Марценюк ${ }^{2}$ В. В. Краснов \\ Національна медична академія післядипломної освіти імені П. Л. Шупика \\ Запорізький державний медичний університет ${ }^{1}$ \\ ДВНЗ «Тернопільський державний медичний університет \\ імені І. Я. Горбачевського МОЗ України» ${ }^{2}$
}

\begin{abstract}
Представлені основні принципи структурної організації комп'ютерних мереж у закладах освіти. Обґрунтовано питання інтеграції ВМ(Ф)НЗ в сучасну інфраструктуру інформаційного суспільства. Детально представлено структурну організацію комп'ютерних мереж. Показано ефективність впровадження автоматизованих бібліотечних інформаційних систем. Акцентовано увагу на необхідність розвитку відкритого навчання.
\end{abstract}

Ключові слова: інформатизація освіти, комп'ютерні мережі, архітектура, відкрите навчання.

\section{КОНЦЕПТУАЛЬНОЕ ОБОБЩЕНИЕ СТРУКТУРНОЙ ОРГАНИЗАЦИИ КОМПЬЮТЕРНЫХ СЕТЕЙ ВЫСШИХ МЕДИЦИНСКИХ УЧЕБНЫХ ЗАВЕДЕНИЙ}

\author{
О. П. Минцер, А. А. Рыжов ${ }^{1}$, В. П. Марценюк ${ }^{2}$, В. В. Краснов \\ Национальная медицинская академия последипломного образования имени П. Л. Шупика \\ Запорожский государственный медицинский университет ${ }^{1}$ \\ ГВУЗ «Тернопольский государственный медицинский университет \\ имени И. Я. Горбачевского МЗ Украины» ${ }^{2}$
}

\begin{abstract}
Представлены основные принципы структурной организации компьютерных сетей в учебных заведениях. Обоснованы вопросы интеграции вузов в современную инфраструктуру информационного общества. Подробно представлена структурная организация компьютерных сетей. Показана эффективность внедрения автоматизированных библиотечных информационных систем. Показана большая динамика нарастания технической и личностной готовности студентов к использованию виртуального образовательного пространства. В связи с этим вузы обязаны обеспечивать опережение по наполнению информационно-образовательной среды виртуального университета современными, в том числе мультимедийными ресурсами по отраслевым образовательным профессиональным программам. На базе информационно-образовательных сред виртуальных представительств вузов должны быть сформированы распределенные ресурсные центры, что позволит исключить дублирование деятельности по развитию инновационных образовательных технологий, обеспечит взаимный обмен достигнутыми результатами и дальнейшее развитие системы открытого непрерывного профессионального образования, обеспечивающей доступность, модульность и мобильность подготовки и переподготовки специалистов.
\end{abstract}

Ключевые слова: информатизация образования, компьютерные сети, архитектура, открытое обучение.

\section{CONCEPTUAL GENERALIZATION OF STRUCTURAL ORGANIZATION OF COMPUTER NETWORKS MEDICAL SCHOOL}

\author{
O. P. Mintser, O. A. Ryzhov ${ }^{1}$, V. P. Martsenyuk ${ }^{2}$, V. V. Krasnov \\ National Medical Academy of Postgraduate Education by P. L. Shupyk \\ Zaporizhzhia State Medical University ${ }^{1}$ \\ SHEI «Ternopil State Medical University by I. Ya. Horbachevsky of MPH of Ukraine» ${ }^{2}$
}

\begin{abstract}
The basic principles of the structural organization of computer networks in schools are presented. The questions of universities integration's in the modern infrastructure of the information society are justified. Details the structural organizations of computer networks are presented. The effectiveness of implementing automated library information systems is shown. The big dynamical growths of technical and personal readiness of students to use virtual educational space are presented. In this regard, universities are required to provide advance information on filling the educational environment of modern virtual university,
\end{abstract}

(C) О. П. Мінцер, О. А. Рижов, В. П. Марценюк, В. В. Краснов 
including multimedia resources for industry professional education programs. Based on information and educational environments virtual representations of universities should be formed distributed resource centers that will avoid duplication of effort on the development of innovative educational technologies, will provide a mutual exchange of results and further development of an open continuous professional education, providing accessibility, modularity and mobility training and retraining specialists.

Key words: informatization of education, computer networks, architecture, open learning.

Вступ. Інтеграція вищого медичного (фармацевтичного) навчального закладу (ВМ(Ф)НЗ) в сучасну інфраструктуру інформаційного суспільства зобов'язує його мати обов'язковий базовий рівень структурної організації комп'ютерних мереж та комп'ютерного забезпечення. Відповідно, для забезпечення принципу рівного доступу до інформаційних ресурсів та принципу мобільності, комп'ютерна ме- режа ВМ(Ф)НЗ повинна мати складну багаторівневу структуру.

Мета роботи. Обгрунтувати основні принципи структурної організації комп'ютерних мереж у вищих медичних навчальних закладах.

Результати та їх обговорення. Розглянемо детально структурну організацію комп'ютерних мереж (КМ) BM(Ф)Н3 (рис. 1).

\section{Єдиний інформаційний простір}

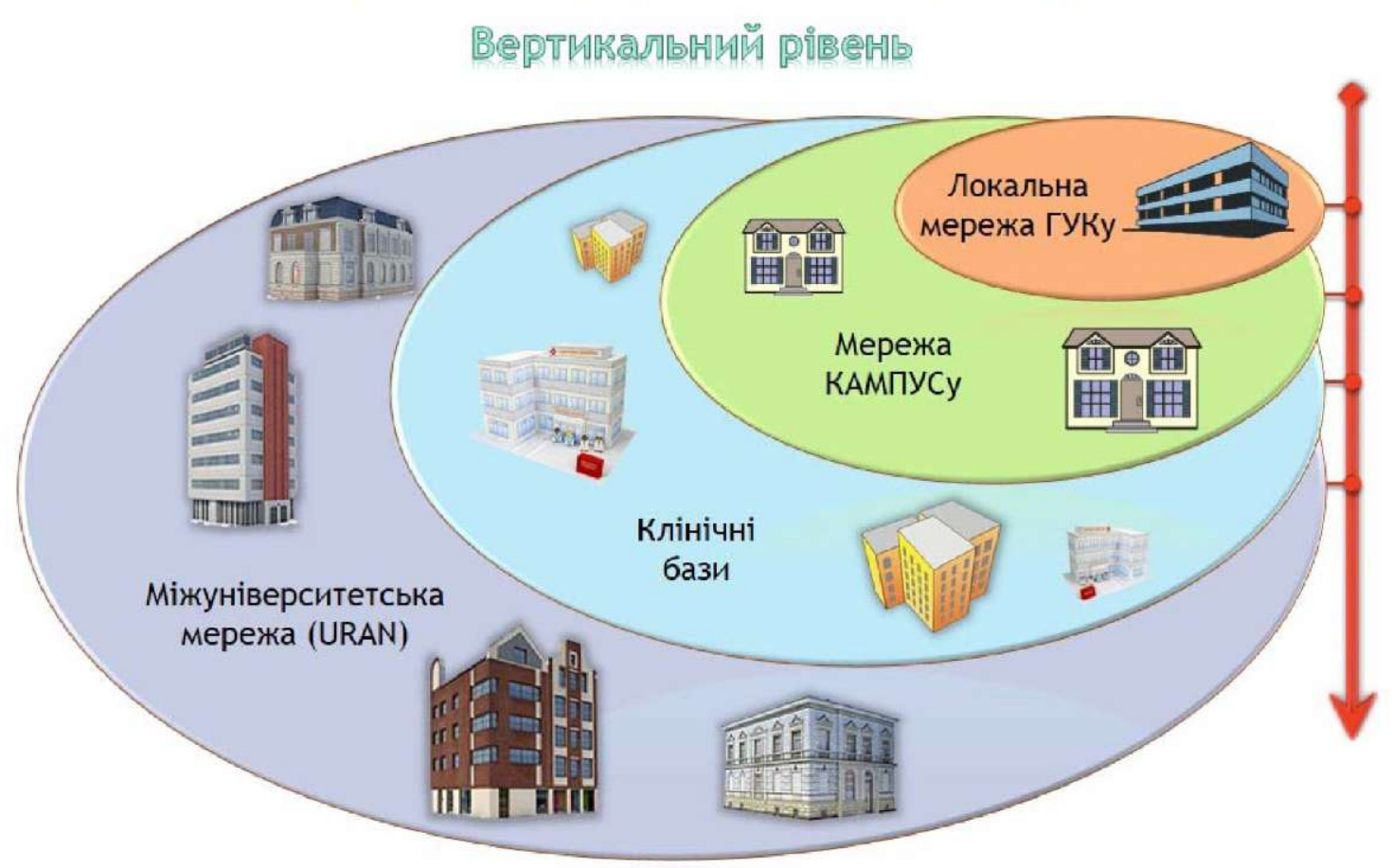

Puc. I. Вертикальний базовий рівень структурної організації комп'ютерних мереж.

Вертикальна структура має:

Перший рівень - локальна мережа (ЛМ), де циркуляція інформації по магістральних каналах забезпечується оптоволоконними каналами зв'язку.

Другий рівень - ЛМ на рівні студентського містечка (КАМПУСА). Основне завдання цієї мережі об'єднати високошвидкісними каналами зв'язку адміністративний корпус з навчальними близько розташованими (1-2 км) корпусами, забезпечити студентам доступ до інформаційних, навчально-методичних ресурсів університету з гуртожитків (1-3 км), а також високоякісними Інтернет-каналами.
Третій рівень - мережа, яка забезпечує інтеграцію до інформаційного простору університету клінічних баз та баз фармацевтичної практики. Технології реалізації КМ різноманітні, та залежать насамперед від об'єму коштів, які виділяються на побудову цієї мережі, по-друге, від можливостей провайдерів Інтернет, по-третє, від інфраструктури міста, де розташовано університет. Найкращий варіант організації цього рівня - оптоволоконні технології, потім технології радіозв'язку (наприклад Wi-Max), далі технології мобільного зв'язку (наприклад 3G). 
Четвертий рівень - це цифрові комунікації, які забезпечують міжвузівський єдиний інформаційний простір. На сьогодні таку мережу було створено асоціацією УРАН, яка об'єднала на безкоштовній основі ВМ(Ф)НЗ України на базі оптичних каналів зв'язку. При відсутності договору з провайдером УРАН використовуються канали зв'язку, які надаються місцевим провайдером.

Горизонтальна структура (рис. 2) має:

Перший рівень - це також рівень локальної мережі. Другий рівень - бездротового зв'язку, формується на базі Wi-Fi технологій. Wi-Fi мережі дозволяють студентам і викладачам активно використовувати особисті комп'ютерні пристрої (КП: ноутбуки, нетбуки, планшети, смартфони) для вирішення освітянських завдань, вільно переміщуючись по території навчального закладу. Розширення використання особистих КП на повсякден- них заняттях дозволяє здійснити перерозподіл фінансування комп'ютеризації ВМ(Ф)Н3 з витрат на створення комп'ютерних класів, серверної бази, інформаційного контенту, придбання ліцензій програмного забезпечення.

Третій рівень - 3G комунікаційні технології. Це рівень мережевого забезпечення, який дозволяє реалізувати концепцію повної мобільності: студент має зв'язок з інформаційними ресурсами або своїми викладачами незалежно від місця знаходження.

Наступний, четвертий рівень інтеграції, впроваджується у випадку необхідності проведення великого обсягу наукових обчислень, це підключення серверного кластера університету до ГРІД-мережі (система кластерів високопродуктивних серверів наукових та навчальних закладів України, об'єднаних високошвидкісними мережами у багатопроцесорний суперкомп'ютер).

\section{Єдиний інформаційний простір}

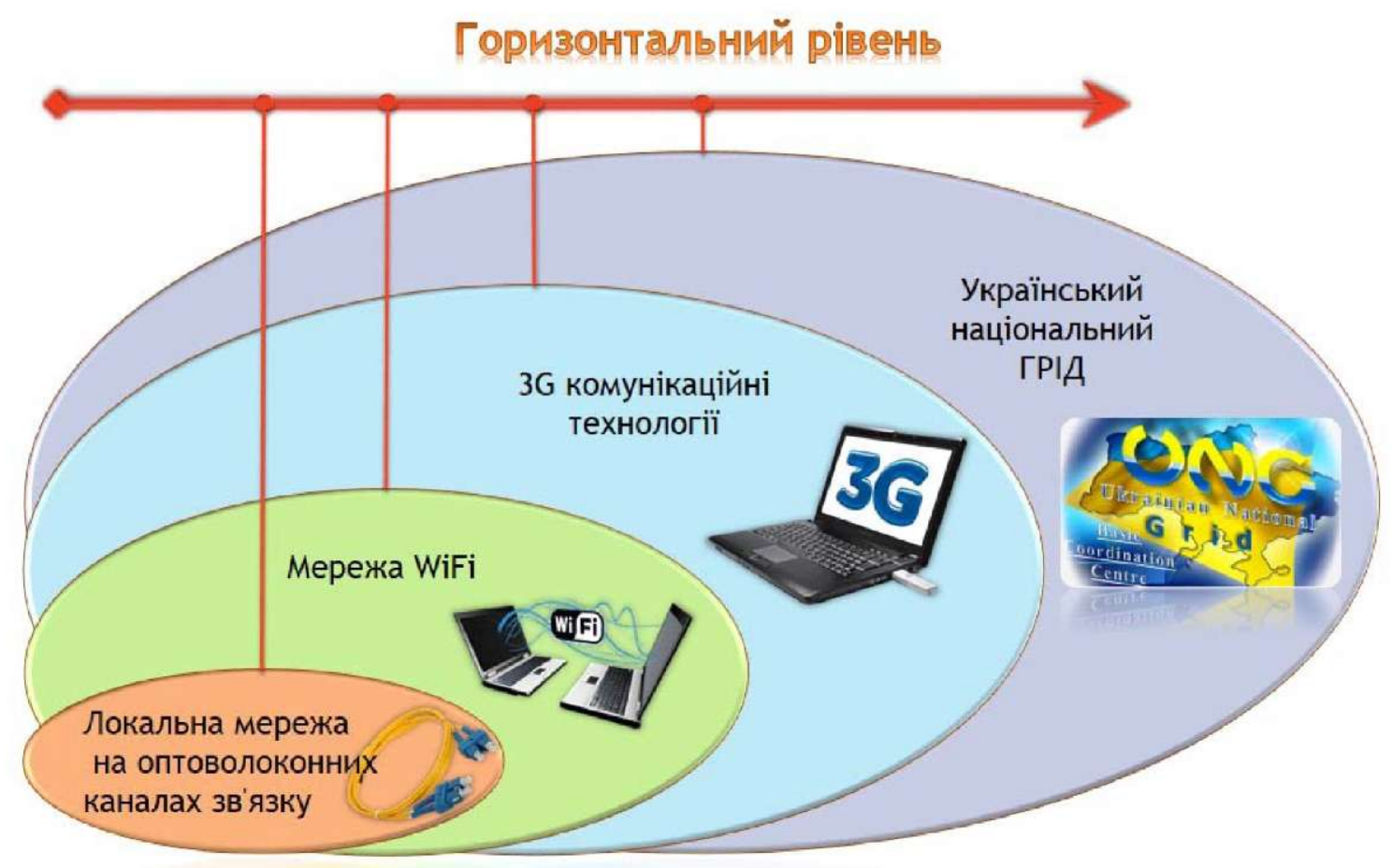

Puc. 2. Горизонтальний базовий рівень структурної організації комп'ютерних мереж.

Архітектура єдиного інформаційно-освітнього комплексу вищого навчального закладу

Концепція єдиного інформаційного простору ВМФЗ реалізована на основі технологій корпоративної мережі, яка інтегрує апаратні ресурси локальної комп'ютерної мережі (ЛКМ) з ресурсами клінічних баз і баз практик (рис. 3). Управління ЛКМ ВМ(Ф)НЗ правами доступу і інформаційними ресурсами користувачів здійснюється на основі сервера активного каталогу (Active Directory) під управлінням OC MS Server $20 \mathrm{I} 2$ R2, в якому відображена інфраструктура підрозділів університету. Така організація дозволяє створювати середовище для інтеграції управлінських процесів і технологій створення навчальних і контролюючих програм. Інформаційні ресурси розміщені на сервері електронної бібліотеки, сервері електронного ката- 
лога, що працює на основі програмного забезпечення «ІРБІС», Web-сервері університету, сервері на- вчальних і контролюючих курсів (RATOS®, Moodle), файл-сервері архіву відеоматеріалів.

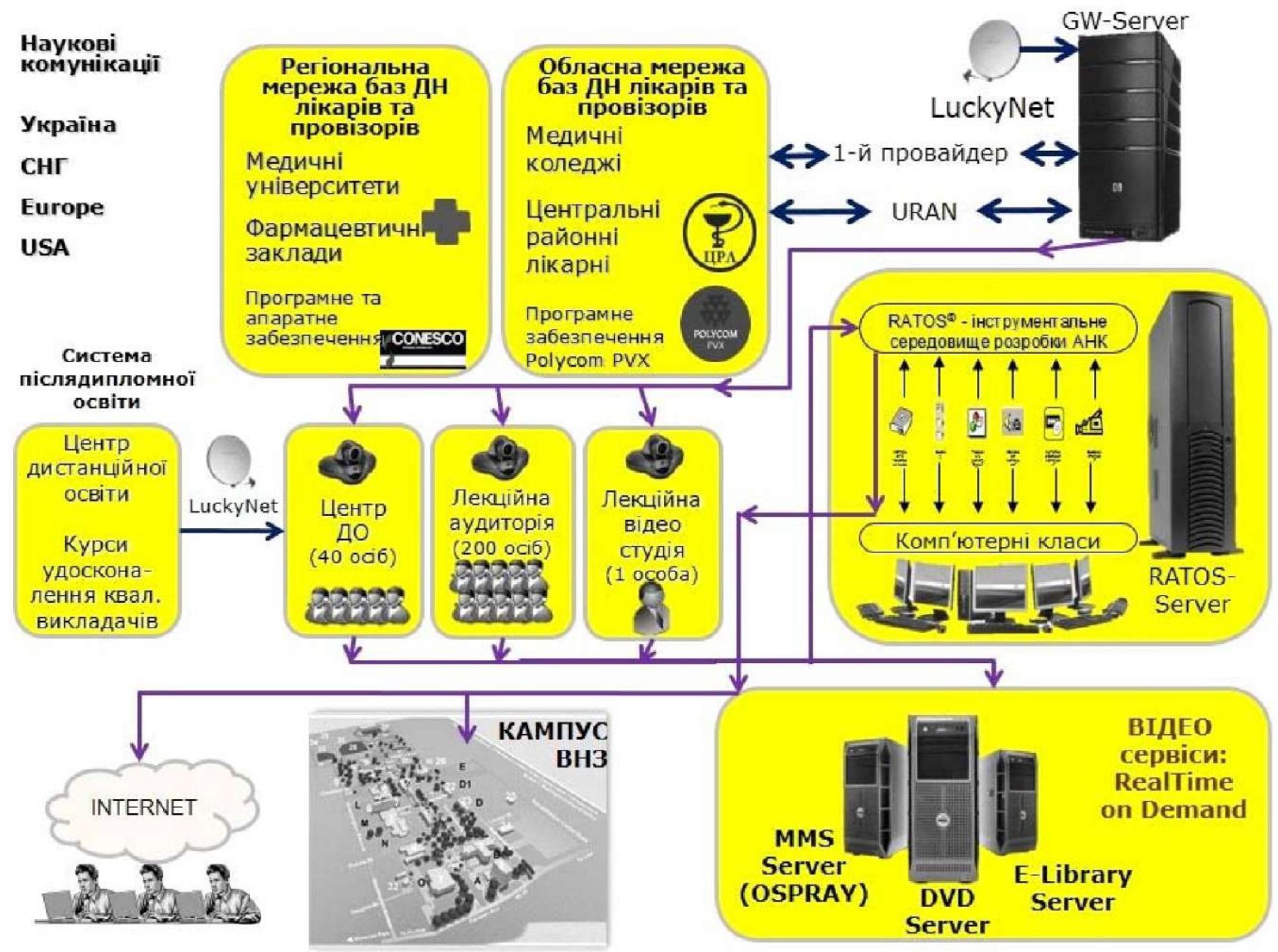

Puc. 3. Структурна організація інформаційно-освітнього комплексу ВМ(Ф)НЗ для навчання лікарів (провізорів) засобами IKT.

Рівень розвитку системи цифрових комунікацій в Україні, а також швидкість і якість виділених каналів зв'язку, що надаються провайдерами Інтернет-сервісу, дозволяє використовувати в навчальному процесі інноваційні технології відеоконференцій. Базис для дистанційної освіти реалізується на основі технології корпоративної мережі, що працює на основі Інтернет-протоколів. Ядром цієї системи є локальні комп'ютерні мережі на базі адміністративного корпусу.

Адміністративний рівень управління комп'ютерною мережею та службами інформаційного забезпечення

1. Сервер активного каталога LDAP (AD);

2. Сервер міжвузівської мережі URAN;

3. Сервер Інтернет;

4. Сервер документообігу університету SharePoint;
5. Сервер веб-ресурсів університету;

6. Сервер додатків (Application);

7. Сервер FTP навчально-методичної літератури та навчальних елементів;

8. Сервер інформаційної системи документообігу;

9. Сервер бухгалтерії (Accounting);

10. Сервер університетської клініки;

11. Сервер дистанційної освіти (DL);

12. Сервер контрольно-навчальної системи RATOS (Moodle);

13. Сервер бібліотечно-інформаційної системи IRBIS MARC;

14. Сервер єдиної платформи комунікацій LYNC;

15. Сервер контингент (автоматизація роботи відділів вузу з обліку руху контингенту);

16. Інші сервери. 
Служба активного каталога

Служба активного каталога, реалізована в MS Windows Server 20I2 R2, дозволяє досить ефективно керувати ресурсами мережі і профілями користувачів. При проектуванні інфраструктури активного каталога можна застосувати два підходи: відображення організаційної структури ВМ(Ф)НЗ і рольовий підхід. У першому випадку для кожного підрозділу ректорату, що має більше двох комп'ютерів, і для кожної кафедри, описувалися використовувані ресурси і формувалася політика користувачів. При рольовому підході відображалася структурна організація учасників навчального процесу університету і реєструвалися загальні ресурси, доступні для їхньої роботи. Аналіз учасників навчального процесу і їхньої взаємодії з ресурсами мережі дозволив визначити ролі, що вказані у таблиці I.

Таблиця І. Ролі користувачів єдиного інформаційно-освітнього середовища, робота якого забезпечується службами активного каталога

\begin{tabular}{|c|c|c|}
\hline Роль & Функщія & Доступ до інформаційних ресурсів \\
\hline $\begin{array}{l}\text { Редактор інформаційних } \\
\text { ресурсів кафедри }\end{array}$ & $\begin{array}{l}\text { Відповідає за створення і зміст сайту } \\
\text { кафедри на Wеb-сервері університету, } \\
\text { представлення методичних матеріалів } \\
\text { на серверах університету }\end{array}$ & $\begin{array}{l}\text { Каталоги кафедри на Web-cервері } \\
\text { університету, } \\
\text { FTP - і файл серверах }\end{array}$ \\
\hline Адміністратор бібліотеки & $\begin{array}{l}\text { Розширення фондів бібліотеки } 3 \\
\text { розділу кафедри і редагування текстів } \\
\text { у разі потреби }\end{array}$ & $\begin{array}{l}\text { Сервер бібліотеки повнотекстових } \\
\text { документів }\end{array}$ \\
\hline Розроблювач АНС і АКК & $\begin{array}{l}\text { Розробка навчальних і контролюючих } \\
\text { елементів і їхніх шаблонів }\end{array}$ & $\begin{array}{l}\text { Сервер навчальних елементів, } \\
\text { бібліотеки й інтерфейсу } \\
\text { розроблювача АСДН }\end{array}$ \\
\hline $\begin{array}{l}\text { ач, шо планус сеанс } \\
3 \text { АСДН }\end{array}$ & Розробка сценаріїв навчання в АСДН & $\begin{array}{l}\text { Сервер навчальних елементів, } \\
\text { бібліотеки й інтерфейсу викладача }\end{array}$ \\
\hline $\begin{array}{l}\text { Оператор, що проводить } \\
\text { сеанс роботи слухача } 3 \text { АСДН }\end{array}$ & $\begin{array}{l}\text { Організація і проведення роботи } \\
\text { слухача в комп'ютерному класі }\end{array}$ & Інтерфейс оператора АСДН \\
\hline $\begin{array}{l}\text { Слухач - окремий обліковий } \\
\text { запис для кожного } \\
\text { факультету і курсу }\end{array}$ & $\begin{array}{l}\text { Самостійна робота з навчальними і } \\
\text { контролюючими програмами, } \\
\text { ресурсами бібліотеки і сайту кафедри }\end{array}$ & $\begin{array}{l}\text { Сервер бібліотеки, мережеві } \\
\text { ресурси, описані в профілі } \\
\text { користувача, відносно його ролі }\end{array}$ \\
\hline $\begin{array}{l}\text { Інтерн або слухач ФПО - } \\
\text { окремий обліковий запис для } \\
\text { кожного факультету }\end{array}$ & $\begin{array}{l}\text { Самостійна робота з навчальними і } \\
\text { контролюючими програмами, } \\
\text { ресурсами бібліотеки і сайту кафедри }\end{array}$ & $\begin{array}{l}\text { Сервер бібліотеки, мережеві } \\
\text { ресурси, описані в профілі } \\
\text { користувача, відносно його ролі }\end{array}$ \\
\hline
\end{tabular}

Організація типової інформаційної системи бібліотеки $B M(\Phi) H 3$

Характерною рисою сучасного стану розвитку бібліотечно-інформаційної діяльності є постійне збільшення потоків саме електронної інформації, кількості електронних документів і створення електронних бібліотек. Необхідність задоволення інформаційних потреб сучасних користувачів за рахунок переваг електронного інформаційно-комунікаційного середовища ставить перед бібліотекою завдання комплектування фондів електронними ресурсами та забезпечення техніко-технологічних умов їх надання та використання.

В основі успішного функціонування сучасної наукової бібліотеки лежить автоматизована система пошуку інформації, наявність доступу до віддалених баз даних через телекомунікаційні мережі та можливість адаптації програмного забезпечення до складних бібліотечних технологічних процесів [I].
Для того, щоб бібліотека вузу стала новим інноваційним центром, необхідна наявність сучасної комп'ютерної техніки; Web-каналів зв'язку (Інтернет); повнотекстових БД довідкової, навчальної і наукової літератури; сервісних послуг; висококваліфікованого персоналу, готового до інновацій; та, нарешті, координації діяльності бібліотеки 3 науково-освітньою діяльністю ВМ(Ф)НЗ (рис. 4).

Впровадження автоматизованих бібліотечних інформаційних систем (АБІС) дає змогу забезпечити комп'ютеризацію всіх напрямків діяльності Бібліотеки і на базі наявного програмно-технічного комплексу дозволить здійснювати наступні процеси:

- дистанційне замовлення нових документів і контроль повноти виконання, реєстрацію надходжень;

- передплату періодичних видань;

- введення відомостей про нові надходження в електронний каталог (ЕК);

- ретроконверсію традиційних каталогів; 
- пошук інформації в ЕК;

- підготовку й видання інформаційних матеріалів;

- персональну реєстрацію користувачів;

- замовлення документів через ЕК;

- видачу літератури на абонементах;
- інтерактивну взаємодію в межах корпоративної бібліотечної мережі;

- одержання різних вихідних даних, обробку статистичної інформації.

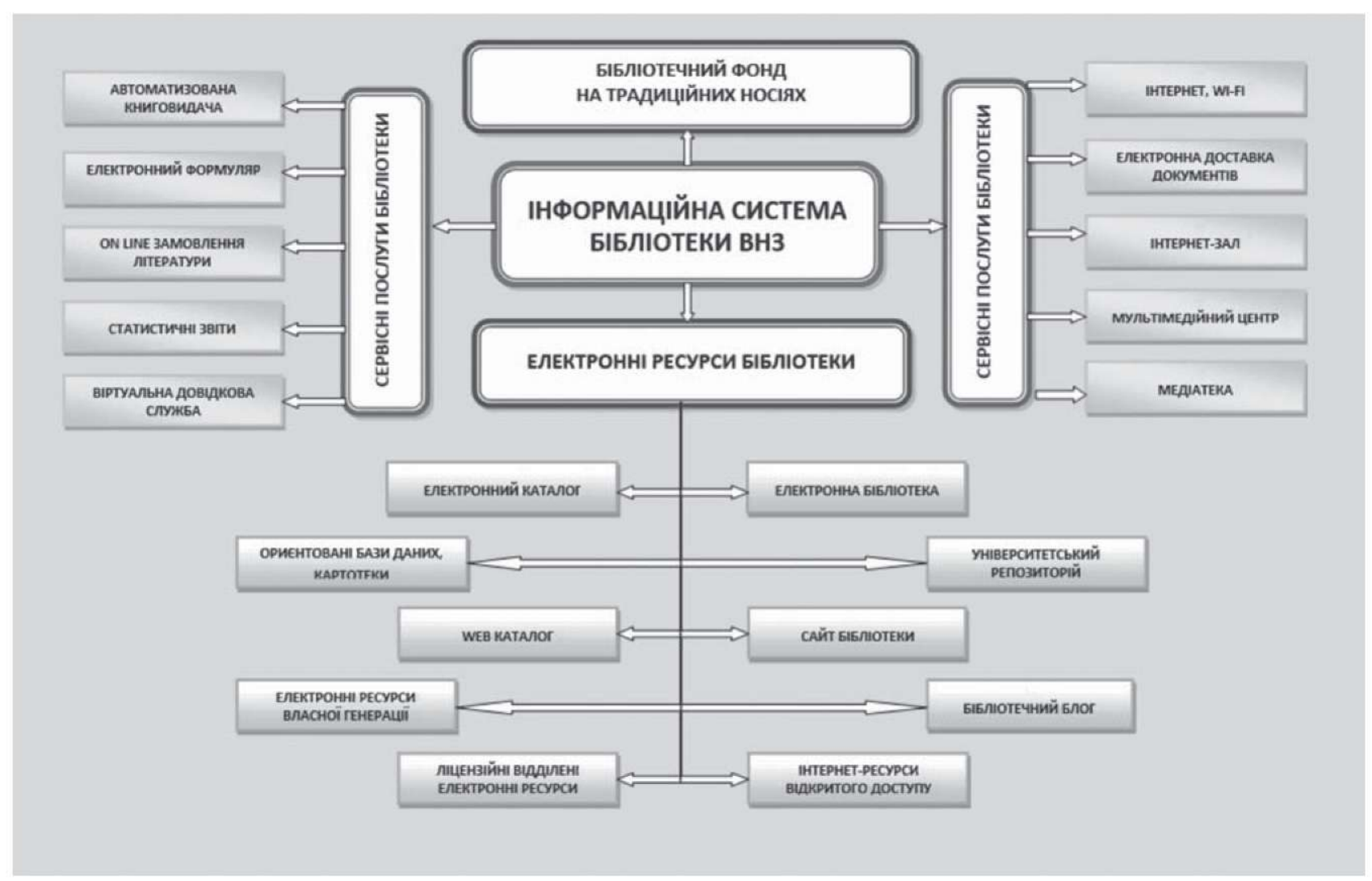

Puc.4. Типова інформаційна система бібліотеки ВМ(Ф)НЗ.

Основні характеристики автоматизованої бібліотеки ВМ(Ф)НЗ:

- робота в локальних та глобальних мережах без обмеження кількості користувачів;

- повна інтеграція в корпоративні бібліотечні системи та технології на основі засобів підтримки Webтехнологій та протоколу 739.50 та повної сумісності 3 міжнародними форматами UNOMARK, MARC21 та Російським комунікативним форматом ЯШМАЯС;

- онлайнова корпоративна робота різних користувачів системи;

- підтримка довільної кількості баз даних, що становлять електронний каталог або є проблемно-орієнтованими бібліографічними базами даних;

- наявність технології автоматичного формування словників, на основі яких реалізується швидкий пошук за будь-якими елементами опису та їх поєднаннями;
- наявність засобів для ведення і використання файлів, алфавітно-предметного покажчика до УДК/ ББК та Тезауруса;

- підтримка традиційних "паперових" технологій: від Друку аркуша замовлення та книги сумарного обліку до друку всіх видів каталожних карток;

- підтримка технологій, що орієнтовані на використання штрих-кодів та радіоміток (RFID) на екземплярах видань та читацьких квитках;

- робота з графічними, аудіовізуальними даними та іншими зовнішніми об'єктами (включаючи ресурси Internet);

- наявність інструментів для створення та підтримки повнотекстових баз даних ("'Електронна бібліотека");

- багатомовність на основі UNICODE;

- наявність засобів для перекладу інтерфейсів користувача на інші мови;

- формально-логічний контроль даних, в тому числі орфографічний; 
- наявність засобів, що забезпечують зручність та наочність призначених для користувача інтерфейсів, спрощують процес введення, виключають помилки та дублювання інформації;

- можливість адаптації до умов роботи конкретної бібліотеки, включаючи засоби створення індивідуальних робочих профілів для всіх категорій користувачів;

- відкритість, що дозволяє користувачу самостійно вносити зміни в широких межах: від зміни вхідних та вихідних форм до розробки оригінальних додатків.

У системі повинні бути реалізовані технології автоматизації всіх типових бібліотечних процесів на основі взаємозв'язаного функціонування модулів АРМ: "Адміністратор"; "Каталогізатор"; "Комплектатор"; "Книговидача"; "Книгозабезпеченість"; "Читач".

Основою для функціонування сучасної IC є її апаратне забезпечення, що включає такі групи устаткування:

1. Комп'ютерний парк ВМ(Ф)Н3 (сервери та робочі станції).

2. Мережеве та телекомунікаційне обладнання, зокрема структуровані кабельні системи, комунікаційні вузли.

3. Спеціалізоване обладнання (діагностичне, лабораторне тощо).

Формування комп'ютерного парку ВМ(Ф)Н3 повинно бути зорієнтовано на довготривале використання. Загальні рекомендації щодо формування комп'ютерного парку серверів та робочих станцій $\mathrm{BM}(\Phi) \mathrm{H} 3$ :

- рекомендується застосування техніки тих виробників, марок і моделей, які отримали кращі оцінки за критеріями "Надійність" та "Довговічність";

• продуктивність вказаних ПК повинна відповідати вимогам до сучасних програмних продуктів, зокрема, для відтворення відео високої чіткості (HO) та потокового контенту (онлайн-відео);

- продуктивність вказаних ПК повинна забезпечувати комфортну роботу в сучасних ОС та орієнтовну можливість запуску наступного покоління ОС (за наявності технічних даних про такі);

- слід віддавати перевагу робочим станціям 3 більшими обсягами оперативної пам'яті (ОЗП) та багатоядерними процесорами.

- $є$ припустимим застосування б/к робочих станцій бізнес-класу від провідних виробників. Вказана техніка при терміні попередньої експлуатації не більше 4-5 років по продуктивності і надійності перевищує відповідні показники для нових ПК бюджетного рівня.

У зв'язку з все більшим поширенням технологій віртуалізації, при формуванні комп'ютерного парку серверів ВМ(Ф)НЗ додатково рекомендується:
- застосовувати сервери з максимально великими обсягами ОЗП та спеціалізованими серверними багатоядерними процесорами;

- використання серверів з RAID-контролерами (дисковий масив 3 надлишковістю);

- більшу цінність мають мережеві комплекси (кластери) з кількох менш потужних серверів у порівнянні з одиничними максимальної потужності;

- виходячи з попереднього, є припустимим застосування б/к серверів. Дане обладнання виготовляється лише провідними виробниками за найвищими стандартами. Вартість б/к серверів 3 терміном експлуатації 5-8 років суттєво нижче від нових, що дає можливість створити кластери 3 більшим числом вузлів та додатковим резервуванням потужностей;

- Рекомендується наявність у серверів систем резервування живлення.

Формування мережевої інфраструктури ВМ(Ф)НЗ повинно бути зорієнтовано на ще більш довготривале використання, ніж парку ПК та серверів. Загальні рекомендації щодо формування мережевої інфраструктури ВМ(Ф)НЗ:

Застосування лише сучасних стандартів побудови комп'ютерних та телекомунікаційних мереж. Зокрема, застосування технологій $1 \mathrm{~Gb}$ Ethernet та підготовка інфраструктури до впровадження 10Gb Ethernet, розбудова мобільних мереж в стандарті IEEE 802.11n.

- Використання інтелектуального комунікаційного обладнання 3 можливістю керування сегментами мережі.

- Категорично не рекомендується використання б/к обладнання, навіть від провідних виробників.

- Проектування, планування та документування процесу розбудови комп'ютерних мереж.

Рекомендація щодо формування парку спеціалізованого обладнання (діагностичного, лабораторного тощо) ВМ(Ф)НЗ:

- Використання моделей (модифікацій, комплектацій), що обладнані комп'ютерними інтерфейсами та комплектуються програмним забезпеченням для архівування, обробки та аналізу отриманої інформації або використовують сумісні протоколи обміну даних, що є міжнародними стандартами (наприклад DICOM).

Створення умов для забезпечення відкритого навчання

Останнє десятиліття ознаменувалося активним рухом, коли окремі викладачі й цілі університети стали не тільки відкривати вільний доступ до освітнього контенту, але й підтримувати вільне навчання будьякого бажаючого [2]. 
Одним з перших проектів відкритого доступу, який подав приклад багатьом іншим університетам, став проект Массачусетського технологічного інституту (MIT OpenCourseWare), метою якого була вільна публікація матеріалів всієї своєї освітньої програми. Починаючи зі старту в 2002 році по 2009 рік МІT безрезультатно намагався монетизувати цей проект: від дистанційної освіти та реклами до продажу очних спецкурсів. Тоді організатори ОCW оголосили проект некомерційним і залучили інвестиції фондів. Через кілька років з'ясувалося, що, окрім підвищення авторитету, проект приносить МІТ пряму користь, залучаючи кращих студентів. Близько 35 \% студентів MIT сказали, що на їх вибір до вступу вплинув OCW. Kрім того, OCW підвищив якість викладання всередині самого навчального закладу, оскільки професори стали підходити більш відповідально до підготовки матеріалів, які публікуються для широкої аудиторії. Крім того, результати дослідження показали, що більше половини аудиторії - люди, які займаються самоосвітою.

ЮНЕСКО підтримав ініціативу створення відкритих освітніх ресурсів. У цьому проекті сьогодні беруть участь близько 150 найбільших університетів 3 21 країни світу, кожен з яких надав у відкритий доступ власні навчальні матеріали в рамках консорціуму Open Соитее Ware (http://www.ocwconsortium.org/) [3].

Відкрита освіта для сьогоднішнього дня - це принципово нова перспективна модель освітнього процесу, стратегія і тактика відносин і взаємодій того, хто навчається, та викладачів в умовах вибору пріоритетів і дій. Новій моделі підготовки фахівців притаманні: міждисциплінарність; методологічний плюралізм; відкритість процесу пізнання; випереджаючий характер (націленість на проблеми майбутнього); підвищена доступність освіти (на основі інформаційних і телекомунікаційних технологій); можливість постійного і швидкого оновлення і поповнення знань без відриву від основної роботи; креативність як необхідна умова підвищення творчого начала; свобода вибору індивідуальної програми навчання з запропонованого набору навчальних курсів; свобода у виборі темпу навчання за рахунок прийому протягом усього навчального року та відсутності фіксованих термінів навчання; свобода у виборі місця навчання [4].

Модель відкритої безперервної медичної професійної освіти можна представити у вигляді інформаційної навчальної системи (IНC), орієнтованої на людину, здатну до самоорганізації, розвитку їі здібностей на основі набуття знань і оволодіння методологією їх використання в житті і професійній діяльності 3 метою найбільш повної реалізації в умовах формування і функціонування суспільства 3 інноваційною економікою.

Основним завданням проектування систем безперервної відкритої професійної освіти як дослідницької діяльності є розробка етапів формування змісту (контенгу) інформаційно-освітнього середовища методами педагогічного проектування. В інформаційно-освітньому середовищі здійснюється проектування об'єктів і явищ нелінійного типу, що володіють складною структурою змісту та організації взаємозв'язку 3 системними елементами середовища.

В основу проектування повинні бути покладені цілі безперервної професійної підготовки фахівців галузі. Ефективність керуючої ролі цілей нерозривно пов'язана з практикою реалізації і результатами навчання в інформаційно-освітньому середовищі відкритої освіти. У той же час цільові вимоги до знань і вмінь фахівців мають розмитий характер, що істотно ускладнює їх використання в якості контрольованих в реальному навчальному процесі відкритої освіти. Характеристика випускника не спирається на компетентнісний підхід до кваліфікації. Тому проектування сучасних освітніх програм за рівнями професійної освіти необхідно проводити з урахуванням кваліфікаційних характеристик фахівця, тобто на основі переліку його компетенцій. Стає очевидним, що комплекс навчальних завдань доцільно представляти як ієрархію професійних завдань, що формують компетентність спеціаліста. У рамках такого розуміння можна говорити не про окремі компетенції, а про загальні компетентності фахівця - еталонну модель компетенцій. Звідси випливає актуальність проблемного підходу до визначення і відбору змісту освіти на кожному рівні безперервної професійної підготовки, що дозволить спиратися на структуровану систему мультидисциплінарних модулів в навчальних дисциплінах, які описують професійні завдання.

Щорічний соціологічний моніторинг умов та якості освітніх послуг дозволяє на основі опитувань тих, хто навчається, i SWOT - аналізу сильних і слабких сторін розвитку інноваційної технології навчання приймати рішення про необхідні поліпшення. Інтенсивне зростання попиту на використання електронних середовищ навчання 32004 р. по теперішній час склало більше, ніж 6-кратне збільшення кількості студентів та слухачів, які використовують відкриту освіту. Технічна готовність тих, хто навчається, досить висока - близько 75 \% мають комп'ютер або доступ до нього і вже більше 60 \% можуть використовувати Інтернет в освітніх цілях. 
Висновки. Динаміка наростання технічної та особистісної готовності тих, хто навчається, до використання віртуального освітнього середовища істотна і ВНЗ галузі забезпечують випередження по наповненню інформаційно-освітнього середовища віртуального університету сучасними, в тому числі мультимедійними ресурсами за галузевими освітніми професійними програмами. Практично на базі інформаційно-освітніх середовищ віртуальних пред-

\section{Література}

1. Марценюк В. П. Медична інформатика. Експертні та інструментальні системи в медицині / В. П. Марценюк, А. В. Семенець.- Тернопіль : Укрмедкнига, 2004. - 221 с. 2. Курылев А. С. Инновационные технологии открытого профессионального образования / А. С. Курылев, В. С. Зверев, В. В. Зверев. - Астрахань : Изд. АГТУ, 2008. - 151 с. ставництв ВНЗів галузі сформовані розподілені ресурсні центри, що дасть змогу виключити дублювання діяльності з розвитку інноваційних освітніх технологій, забезпечить взаємний обмін досягнутими результатами і подальший розвиток системи відкритої неперервної професійної освіти в галузі, що забезпечує доступність, модульність і мобільність підготовки та перепідготовки фахівців.

3. Парижская Декларация 2012 г. по ООР. - Режим доступу: http:/www.unesco.org/new/fileadmin/MULTIMEDIA/HQ/CI/ $\mathrm{CI} /$ pdf/Events/RussianParisOERDeclaration.pdf.

4. Курылев А. C. Проектирование систем непрерывного открытого профессионального образования: теория и практика / А. С. Курылев. - Калининград : БГАРФ, 2007. - 138 с. 